\title{
Effect of Vanadium on TLR4 and TLR7 mRNA Expression in the Lymphoid Organs of Broilers
}

\section{Wei Cui, Hengmin Cui*, Xi Peng, Jing Fang, Zhicai Zuo, Xiaodong Liu and Bangyuan Wu}

Key Laboratory of Animal Diseases and Environmental Hazards of Sichuan Province, College of Veterinary Medicine, Sichuan Agricultural University, Ya'an 625014, China

\begin{abstract}
TLRs are important innate immune receptors. It has been found that vanadium can affect the immune function in broilers. However, vanadium action in the regulation of TLRs is unknown. A total of 420 one-day-old avian broilers were divided into six groups, and fed on a corn-soybean basal diet as control diet (vanadium $0.073 \mathrm{mg} / \mathrm{kg}$ ) or the same diet supplemented with vanadium at the doses of $5,15,30,45$ and $60 \mathrm{mg} / \mathrm{kg}$ in the form of ammonium metavanadate. TLR4 and TLR7 mRNA expression in lymphoid organs of each group were studied by real time RT-PCR form. The results indicated that the TLR4 and TLR7 mRNA expression in thymus and TLR4 mRNA expression in bursa were down-regulated in the $60 \mathrm{mg} / \mathrm{kg}$ group. The TLR7 mRNA expression in bursa was down-regulated in $30 \mathrm{mg} / \mathrm{kg}, 45$ $\mathrm{mg} / \mathrm{kg}$ and $60 \mathrm{mg} / \mathrm{kg}$ groups, and up-regulated in the $5 \mathrm{mg} / \mathrm{kg}$ group. Also, the TLR4 and TLR7 mRNA expression in spleen was down-regulated in the $45 \mathrm{mg} / \mathrm{kg}$ and $60 \mathrm{mg} / \mathrm{kg}$ groups, and up-regulated in the $5 \mathrm{mg} / \mathrm{kg}$ group. The abovementioned results showed that dietary vanadium in excess of $30 \mathrm{mg} / \mathrm{kg}$ could down-regulate the TLR4 and TLR7 mRNA expression in lymphoid organs, which finally impaired innate immunity in broilers.
\end{abstract}

Keywords: Dietary vanadium; TLR4; TLR7; Lymphoid organs; Broiler

\section{Introduction}

Vanadium is widely distributed in the environment, and its biological importance appears to be significant $[1,2]$. Vanadium has been proved to be potent inhibitors of several phosphohydrolases, such as ATPase and an activator of adenyl cyclase [3-5]. It has also been suggested to be potent anti-carcinogenic agent [6]. The most of reports about vanadium were focus on the action of insulin as an antidiabetic agent [7-9]. Meanwhile, the toxicity of vanadium also has been found in animals [10].

Recently, there are some studies on the effects of vanadium on immune function. It has been reported that vanadate can affect proliferation and differentiation of the T-cells [11] and activate macrophages [12]. The immunotoxicity of vanadate has been proved [13]. At the same time, the results of our recent studies have shown that high levels of dietary vanadium can cause the lesions in lymphoid organs, inhibit the growth of lymphoid organs, splenic oxidative stress and splenocyte apoptosis, and affect the secretion of immunologic factors and cytokine contents in the mucosal immunity of broilers [14$18]$.

Toll-like receptor (TLR) family mediates the initial interactions of microbial pathogens with cells of an infected host and initiates signaling processes central to the host's innate and adaptive immune responses $[19,20]$. Eight TLR family members have been identified in chick (TLR 1 7 and TLR 15) [21,22]. The TLR4 is the first identified and is responsible for the sensing of lipopolysaccharide (LPS) [23,24]. The TLR7 has been proved to recognize single stranded RNA, as often occurring in viruses [23]. However, there are no reports about the effect of vanadium on the mRNA expression of TLR family. As a part of our study on the effects of dietary vanadium on lymphoid organs (including the bursa of fabricius, spleen, and thymus), the same broilers were used in the present study to investigate the effect of vanadium on the TLR4 and TLR7 mRNA expression in lymphoid organs, and to evaluate the effect of different levels of dietary vanadium on innate immunity of broilers.

\section{Materials and Methods}

\section{Chickens and diets}

Four hundred and twenty healthy, one-day-old avian broilers were divided into six groups. There were seven replicates in each group and ten broilers per replicate. The birds were housed in electrically heated cages and were provided with water and experimental diets ad libitum for 42 days.

A corn-soybean base diet formulated by the NRC (1994) served as the control diet (vanadium $0.073 \mathrm{mg} / \mathrm{kg}$ ). Ammonium metavanadate was mixed into the corn-soybean basal diet to produce experimental diets with vanadium at the doses of $5,15,30,45$ and $60 \mathrm{mg} / \mathrm{kg}$, respectively.

All experimental procedures involving animals were approved by Sichuan Agricultural University Animal Care and Use Committee.

\section{Sample selection}

At the end of experiment, five chickens in each group were humanely killed. The thymus, bursa of Fabricius and spleen were frozen immediately in liquid nitrogen and stored at $-80^{\circ} \mathrm{C}$ until RNA extraction was performed.

\section{RNA isolation and reverse transcription-PCR}

Total RNA was isolated from tissue by sequential extraction with Trizol reagent (Invitrogen). RNA integrity was confirmed by agarose gel electrophoresis, and RNA was quantified by spectrophotometric analysis. Prior to amplification, all RNA samples were treated with RNase-free DNase to preclude genomic DNA contamination.

Reverse transcription (RT) was carried out in a total volume of 10 $\mu \mathrm{L}$ containing $2 \mu \mathrm{L} 5 \times$ Prime script $^{\mathrm{TM}}$ Buffer, $0.5 \mu \mathrm{L}$ Prime script ${ }^{\mathrm{TM}} \mathrm{RT}$

*Corresponding author: Hengmin Cui, PhD, Professor, College of Veterinary Medicine, Sichuan Agricultural University, Ya'an, Sichuan 625014, China, Tel: +86 13608264628; Fax: +86 0835 2882340; E-mail: cuihengmin2008@sina.com; cui580420@sicau.edu.cn

Received April 09, 2012; Accepted August 13, 2012; Published August 16, 2012

Citation: Cui W, Cui H, Peng X, Fang J, Zuo Z, et al. (2012) Effect of Vanadium on TLR4 and TLR7 mRNA Expression in the Lymphoid Organs of Broilers. Med chem 2: 103-106. doi:10.4172/2161-0444.1000123

Copyright: (c) 2012 Cui W, et al. This is an open-access article distributed unde the terms of the Creative Commons Attribution License, which permits unrestricted use, distribution, and reproduction in any medium, provided the original author and source are credited. 
Enzyme Mix, $0.5 \mu \mathrm{L}$ Oligo dT Primer $(50 \mu \mathrm{M}), 0.5 \mu \mathrm{L}$ Random hexamer primers $(100 \mu \mathrm{M}), 1 \mu \mathrm{L}$ Total RNA, $5.5 \mu \mathrm{L}$ RNase Free ddH $\mathrm{d}_{2} \mathrm{O}$. The RT reaction was performed at $37^{\circ} \mathrm{C}$ for $15 \mathrm{~min}$ and $85^{\circ} \mathrm{C}$ for $5 \mathrm{~s}$. A negative control was included in which reverse transcriptase was omitted during the $\mathrm{RT}$ reaction.

\section{Real-Time PCR}

Real-Time PCR was performed to analyze mRNA expression in the lymphoid organs using SYBR Green PCR Mix (TaKaRa, Japan). A total volume of $12.5 \mu \mathrm{L}$ reaction system contained $6.25 \mu \mathrm{L}$ SYBR Premix Ex Taq $(2 \times), 0.25 \mu \mathrm{L}$ each of forward and reverse primers $(10 \mu \mathrm{M})$, $1 \mu \mathrm{L} \mathrm{cDNA}$ and $4.75 \mu \mathrm{L} \mathrm{ddH}_{2} \mathrm{O}$. The sequences for the forward and reverse primers and $\beta$-actin were showed in Table 1. PCR conditions were as follows: pre-denaturation at $95^{\circ} \mathrm{C}$ for $1 \mathrm{~min}$, followed by 40 cycles of denaturation at $95^{\circ} \mathrm{C}$ for $5 \mathrm{~s}$, annealing at $60^{\circ} \mathrm{C}$ for $30 \mathrm{~s}$, and extension at $72^{\circ} \mathrm{C}$ for $30 \mathrm{~s}$. Melting curve conditions were $95^{\circ} \mathrm{C}$ for 0 s, $50^{\circ} \mathrm{C}$ for $30 \mathrm{~s}$ and $95^{\circ} \mathrm{C}$ for $0 \mathrm{~s}$ (temperature change velocity: $0.5^{\circ} \mathrm{C}$ /s). Amplification and melting curve analysis was performed using iQ5 Real-Time PCR Detection System (Bio-Rad, USA). Melting curve analysis was conducted to confirm the specificity of each product. The experiment was repeated three times. The expression of TLR4 and TLR7 mRNA normalization with $\beta$-actin mRNA sample was applied to calculate the relative expression level of each gene.

\section{Serum INF- $\gamma$ by ELISA Assay}

The serum of five birds in each group were taken at 14, 28 and 42 days of age during the experiment. The serum INF- $\gamma$ content was assayed by ELISA Kit for chick (GBD Ltd, USA) according to kit introduction. These results were determined by the standard curve and were expressed as nanogram per milliliter.

\section{Statistical analysis}

The significance of difference among six groups was analyzed by variance analysis, and results presented as means \pm standard deviation $(\bar{X} \pm \mathrm{S})$. The analysis was done under SPSS 12.0 for windows.

\section{Results}

\section{Clinical Observation}

Results showed in the reference [16].

\section{Changes of TLR4 mRNA expression}

The melting curves produced for TLR4 were shown in Figure 1. The Tm of TLR 4 was $83.5^{\circ} \mathrm{C}$. At the Tm, the PCR products produced a melting curve with a single peak. The gene transcripts TLR4 detected by RT-PCR analysis were confirmed by real-time PCR analysis.

The similar TLR4 mRNA expression pattern was observed in the thymus and bursa. The relative expression of TLR4 mRNA in thymus and bursa were depressed $(\mathrm{P}<0.05)$ in the $60 \mathrm{mg} / \mathrm{kg}$ group. The relative expression of TLR4 mRNA in spleen were significantly depressed $(\mathrm{P}<0.01)$ in the $45 \mathrm{mg} / \mathrm{kg}$ and $60 \mathrm{mg} / \mathrm{kg}$ groups, and increased $(\mathrm{P}<0.05)$ in the $5 \mathrm{mg} / \mathrm{kg}$ group. The details were presented in Figure 2.

\section{Changes of TLR7 mRNA expression}

The melting curves produced for TLR7 were shown in Figure 3. The Tm of TLR 4 was $84^{\circ} \mathrm{C}$. At the Tm, the PCR products produced a melting curve with a single peak. The gene transcripts TLR7 detected by RT-PCR analysis were confirmed by real-time PCR analysis.

The relative expression of TLR7 mRNA in thymus was depressed
$(\mathrm{P}<0.05)$ in the $60 \mathrm{mg} / \mathrm{kg}$ group. The similar TLR4 mRNA expression pattern was observed in the bursa and spleen. The relative expression of TLR7 mRNA were significantly depressed $(\mathrm{P}<0.01)$ in bursa of 30 $\mathrm{mg} / \mathrm{kg}, 45 \mathrm{mg} / \mathrm{kg}$ and $60 \mathrm{mg} / \mathrm{kg}$ groups and significantly depressed $(\mathrm{P}<0.01)$ in spleen of the $45 \mathrm{mg} / \mathrm{kg}$ and $60 \mathrm{mg} / \mathrm{kg}$ groups, and increased $(\mathrm{P}<0.05)$ in bursa and spleen of the $5 \mathrm{mg} / \mathrm{kg}$ group. The details were shown in Figure 4.

\section{Changes of the Serum INF- $\gamma$ Contents}

Compared with that of control group, the serum INF- $\gamma$ content was increased $(\mathrm{P}<0.05)$ in the $5 \mathrm{mg} / \mathrm{kg}$ group at 28 days of age, and was markedly decreased $(\mathrm{P}<0.01$ or $\mathrm{P}<0.05)$ in the $45 \mathrm{mg} / \mathrm{kg}$ and $60 \mathrm{mg} / \mathrm{kg}$ groups from 14 to 42 days of age. The results were shown in Table 2.

\section{Discussion}

It is well known that TLR function plays a central role in both host defense against infection and pathological processes such as host toxic reactions to bacterial lipopolysaccharide [25]. Previous reports have described that TLR4 appears to be expressed by macrophages

\begin{tabular}{|c|l|c|c|}
\hline Gene & Primer sequences & Expected size & $\begin{array}{c}\text { GeneBank accession } \\
\text { number }\end{array}$ \\
\hline TLR4 & $\begin{array}{l}\text { F: gagtttgacattgctcggtcct } \\
\text { R: ctccagataagtgttcctcctcag }\end{array}$ & $141 \mathrm{bp}$ & NM_001030693.1 \\
\hline TLR7 & $\begin{array}{l}\text { F: gcttatccccagtcttgtagagc } \\
\text { R: cttagggttccaggttagagagg }\end{array}$ & $117 \mathrm{bp}$ & NM_001011688.1 \\
\hline B-actin & $\begin{array}{l}\text { F: cccaaagccaacagagagaaga } \\
\text { R: gtaacaccatcaccagagtccatc }\end{array}$ & $146 \mathrm{bp}$ & NM_205457.2 \\
\hline
\end{tabular}

Table 1: The primer sequences of target genes and house-keeping gene.

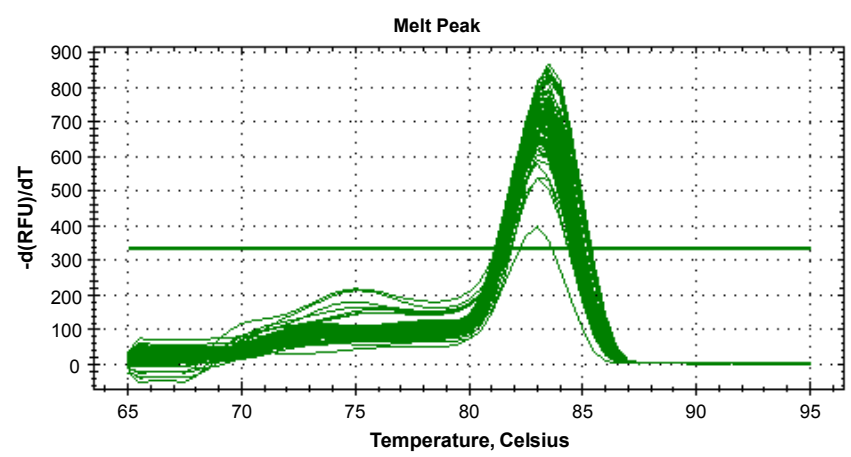

Figure 1: Melting curve analysis of TLR4 gene transcripts detected by realtime PCR: cDNA samples are amplified in real-time PCR with specific set of primers and melting curve analysis is performed to confirm the identity of the PCR products.

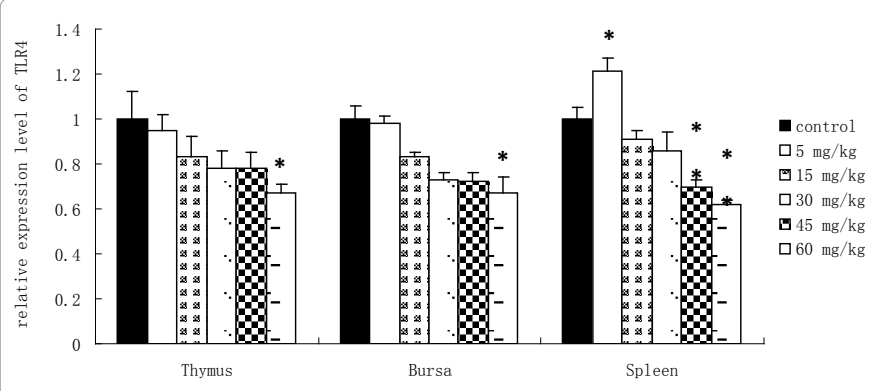

Data are presented as means \pm standard deviation $(n=5)$

${ }^{*} p<0.05$, compared with the control group

${ }^{* *} p<0.01$, compared with the control group

Figure 2: Changes of TLR4 mRNA relative expression. 


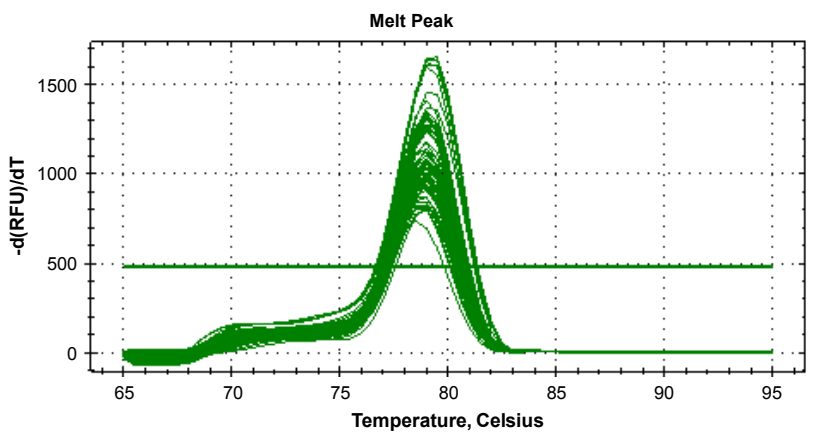

Figure 3: Melting curve analysis of TLR7 gene transcripts detected by realtime PCR: cDNA samples are amplified in real-time PCR with specific set of primers and melting curve analysis is performed to confirm the identity of the PCR products.

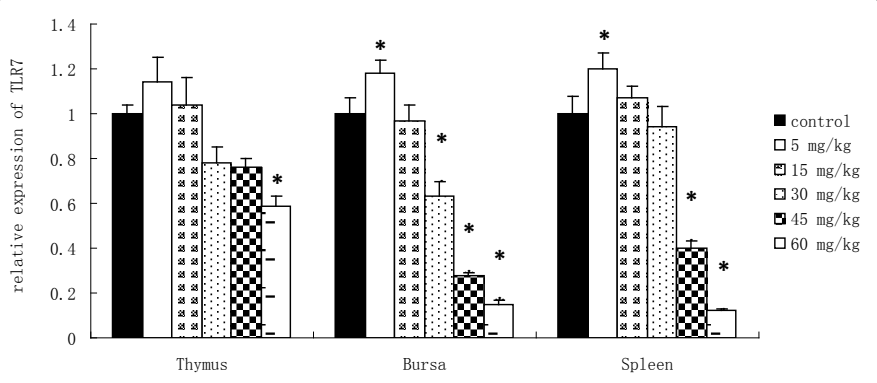

Data are presented as means \pm standard deviation $(n=5)$

${ }^{*} p<0.05$, compared with the control group

${ }^{* *} p<0.01$, compared with the control group

Figure 4: Changes of TLR7 mRNA relative expression.

\begin{tabular}{|c|c|c|c|}
\hline & 14 days & 28 days & 42 days \\
\hline control & $4.30 \pm 0.09$ & $4.34 \pm 0.08$ & $4.33 \pm 0.13$ \\
\hline $5 \mathrm{mg} / \mathrm{kg}$ group & $4.45 \pm 0.08$ & $4.62 \pm 0.15^{*}$ & $4.46 \pm 0.09$ \\
\hline $15 \mathrm{mg} / \mathrm{kg}$ group & $4.26 \pm 0.05$ & $4.55 \pm 0.14$ & $4.34 \pm 0.06$ \\
\hline $30 \mathrm{mg} / \mathrm{kg}$ group & $4.14 \pm 0.09$ & $4.30 \pm 0.14$ & $4.31 \pm 0.07$ \\
\hline $45 \mathrm{mg} / \mathrm{kg}$ group & $4.09 \pm 0.02^{*}$ & $4.01 \pm 0.14^{*}$ & $4.06 \pm 0.08^{* *}$ \\
\hline $60 \mathrm{mg} / \mathrm{kg}$ group & $3.92 \pm 0.15^{* *}$ & $3.90 \pm 0.13^{* *}$ & $3.82 \pm 0.08^{* *}$ \\
\hline
\end{tabular}

Data are presented as means \pm standard deviation $(n=5)$

${ }^{*} p<0.05$, compared with the control group

${ }^{* *} p<0.01$, compared with the control group

Table 2: Changes of the serum INF-y content ( $\mathrm{ng} / \mathrm{ml})$.

and other immune cells, such as mature T-cell and B-cell [26,27] and, TLR7 mRNA is expressed by immune cells including macrophages and B-cell, and is expressed mostly in spleen, lung, and placenta [28-30]. In the present study, we have selected TLR4 and TLR7, and evaluated their mRNA expression in lymphoid organs associated with different levels of dietary vanadium. The data indicated that the TLR4 mRNA expression in thymus and bursa were down-regulated in the $60 \mathrm{mg} /$ $\mathrm{kg}$ group. The TLR4 mRNA expression in spleen was up-regulated in the $5 \mathrm{mg} / \mathrm{kg}$ group and significantly depressed in the $45 \mathrm{mg} / \mathrm{kg}$ and 60 $\mathrm{mg} / \mathrm{kg}$ groups. The TLR7 mRNA expression in thymus was the same as TLR4. The TLR7 mRNA expression was down-regulated in bursa of the $30 \mathrm{mg} / \mathrm{kg}, 45 \mathrm{mg} / \mathrm{kg}$ and $60 \mathrm{mg} / \mathrm{kg}$ groups, and down-regulated in spleen of $45 \mathrm{mg} / \mathrm{kg}$ and $60 \mathrm{mg} / \mathrm{kg}$ groups. However, The TLR7 mRNA expression was up-regulated in bursa and spleen of $5 \mathrm{mg} / \mathrm{kg}$ group.

To our knowledge, no direct evidence to explain the reason that different levels of dietary vanadium can affect TLR4 and TLR7 mRNA expression. A possibility is associate with the lesions of lymphoid organs and the cytokines secretion. The lesions in lymphoid organs induced by dietary high vanadium have been observed in our recent research [1415] and other previous reports [31]. The lesions can cause decrease in cell population in the lymphoid organs, which leads down-regulation in TLR4 and TLR7 mRNA expression. Meanwhile, the TLR mRNA expression can be regulated by cytokines, such as INF- $\gamma$ [32,33]. INF- $\gamma$ is produced by T-cell and NK cell [34], and can activate macrophages [35]. It was observed in the present study that dietary vanadium at the doses of 45 and $60 \mathrm{mg} / \mathrm{kg}$ could inhibite INF- $\gamma$ secretion. Therefore, decreased INF- $\gamma$ contents could inhibit the activity of macrophages, and lead TLR4 and TLR7 mRNA expression down-regulation finally.

The other factors, such as oxidative stress induced by vanadium, also should be concerned. The oxidative stress induced by high vanadium has been proved in broilers [16,36,37]. Oxidative stress induces free radical generation that may modulate TLR mRNA expression [38]. Also, free radical generation induced by high vanadium could damage DNA and RNA directly [39] and, the TLR mRNA expression was down-regulated by high vanadium through this way. In additional, the changes of TLR4 and TLR7 mRNA expression in the three lymphoid organs induced by vanadium were different. The effect of vanadium on TLR4 and TLR7 mRNA expression in bursa and spleen were more obvious than in thymus. This distinction may be concerned with the components of cells in these lymphoid organs and the extent of vanadium-induced lesions.

In conclusion, dietary vanadium in excess of $30 \mathrm{mg} / \mathrm{kg}$ can downregulate TLR4 and TLR7 mRNA expression in lymphoid organs, which finally impairs the innate immunity in broilers.

\section{Acknowledgment}

The study was supported by the program for Changjiang scholars and innovative research team in university (IRT 0848) and the key program of Education Department and Scientific department of Sichuan Province (09ZZ017).

\section{References}

1. French RJ, Jones PJ (1993) Role of vanadium in nutrition: metabolism essentiality and dietary consideration. Life Sci 52: 339-346.

2. Nielsen F H (1990) New essential trace elements for the life sciences. Bio Trace Elem Res 26-27: 599-611.

3. Nørgaard A, Kjeldsen K, Hansen O, Clausen T (1983) A simple and rapid method for the determination of the number of $3 \mathrm{H}$-ouabain binding sites in biopsies of skeletal muscle. Biochem Biophys Res Commun 111: 319-325.

4. Bahdan RN (1984) Mechanisms of action of vanadium. Ann Rev Pharmcal Toxical 24: 501-507.

5. Schmitz W, Scholz H (1982) Effcet of vanadium in the $+5,+4$ and +3 oxidation states on cardiac force of contraction, adenylate cyclase and $\left(\mathrm{Na}^{+}, \mathrm{K}^{+}\right)$-ATPase activity. Biochem Pharmacol 31: 3853-3860

6. Bishayee A, Chatterjee M (1995) Time course effects of vanadium supplement on cytosolic reduced glutathione level and glutathione S-transferase activity. Biol Trace Elem Res 48: 275-285.

7. Duckworth WC, Solomon SS, Liepnieks J (1998) Insulin-like effects of vanadium in isolated rat adipocytes. Endoerinol 122: 2285-2289.

8. Crans DC, Smee JJ, Gaidamauskas E, Yang L (2004) The Chemistry and biochemistry of vanadium and the biological activities exerted by vanadium compounds. Chem Rev 104: 849-902.

9. Domingo JL (2002) Vanadium and tungsten derivatives as antidiabetic agents: a review of their toxic effects. Biol Trace Elem Res 88: 97-112.

10. Bartha A, Schaffera AW, Konnarisa C, Blauensteinera R, Winkera R, et al (2002) Neurobehavioral effects of vanadium. J Toxicol Environ Health Part $A$ 65: 677-683.

11. Qureshi MA, Hill CH, Heggen CL (1999) Vanadium stimulates immunological responses of chicks. Vet Immunol Immunopathol 68: 61-71. 
Citation: Cui W, Cui H, Peng X, Fang J, Zuo Z, et al. (2012) Effect of Vanadium on TLR4 and TLR7 mRNA Expression in the Lymphoid Organs of Broilers. Med chem 2: 103-106. doi:10.4172/2161-0444.1000123

12. Ramanadham M, Kern M (1983) Differential effect of vanadate on DNA synthesis induced by mitogens in T and B lymphocytes. Mol Cell Biochem 51: 67-71.

13. Mravcová A, Jírová D, Jancí $H$, Lener J (1993) Effects of orally administered vanadium on the immune system and bone metabolism in experimental animals. Sci Total Environment 134: 663-669.

14. Cui W, Cui H, Peng X, Fang J, Zuo Z, et al. (2011) Changes in relative weight, lesions, and cell cycle of bursa of Fabricius induced by dietary excess vanadium in broilers. Biol Trace Elem Res 143: 251-260.

15. Cui W, Cui H, Peng X, Fang J, Zuo Z, et al. (2011) Dietary excess vanadium induces lesions and changes of cell cycle of spleen in broilers. Biol Trace Elem Res 143: 949-956.

16. Cui W, Cui H M, Peng Xi, et al (2012) Dietary vanadium induces decrease in antioxidant enzyme activities and oxidative stress in the spleens of broilers. Med Chem 2: 110.

17. Wei C, Hengmin C, Xi P, Jing F, Xiaodong L, et al. (2012) Effect of Vanadium on Splenocyte Apoptosis in Broilers. Med chem 2: 057-060.

18. Deng Y, Cui H, Peng X, Fang J, Zuo Z, et al. (2012) The Relevance of Cytokines for Mucosal Immunity Induced By Dietary Vanadium in the Intestine of Broilers. Med chem 2: 114.

19. Taked AK, Kaisho T, Akira S (2003) Toll-like receptors. Ann Rev Immunol 21 335-376.

20. Akira S, Taked A K (2004) Toll-like receptor signaling. Nat Rev Immunol 4 499-511.

21. Yilmaz A, Shen S, Adelson DL, Xavier S, Zhu JJ (2005) Identification and sequence analysis of chicken Toll-like receptors. Immu-nogenetics 56: 743753

22. Higgs R, Cormican P, Cahalane S, Allan B, Lloyd AT, et a1. (2006) Induction of a novel chicken Toll-like receptor following Salmonella enterica serovar typhimurium infection. Infect Immun 74: 1692-1698.

23. Thomas W, Katja F, Iwan A, Dirk W (2011) Toll-like receptors in domestic animals. Cell Tissue Res 343: 107-120.

24. Shimazu R, Akashi S, Ogata H, Nagai Y, Fukudome K, et al. (1999) MD-2, a molecule that confers lipopolysaccharide responsiveness on Toll-like receptor 4. J Exp Med 189: 1777-1782.

25. Gillespie M, Shamovsky V, D'Eustachio P (2011) Human and chicken TLR pathways: manual curation and computer-based orthology analysis. Mamm Genome 22: 130-138.

26. Wassef A, Janardhan K, Pearce JW, Singh B (2004) Toll-like receptor4 in normal and inflamed lungs and other organs of pig, dog and cattle. Histol Histopathol 19: 1201-1208.

27. Tirumurugaan KG, Dhanasekaran S, Raj GD, Raja A, Kumanan K, et al. (2010) Differential expression of toll-like receptor mRNA in selected tissues of goat (Capra hircus). Vet Immunol Immunopathol 15: 296-301.

28. Du X, Poltorak A, Wei Y, Beutler B (2000) Three novel mammalian Toll-like receptor: gene structure, expression, and evolution. Eur Cytokine Netw 11 362-371.

29. Edwards AD, Diebold SS, Slack EM, Tomizawa H, Hemmi H, et a1. (2003) Toll-like receptor expression in murine DC subsets: lack of TLR7 expression by $C D 8 \alpha+D C$ correlates with unresponsiveness to imidazoquinolines. Eur $J$ Immunol 33: 827-833.

30. Hornung V, Rothenfusser S, Britsch S, Krug A, Jahrsdörfer B, et a1. (2002) Quantitative expression of Toll-like receptor I-10 mRNA in cellular subsets of human peripheral blood mononuclear cells and sensitivity to $\mathrm{CpG}$ oligodeoxynucleotides. J Immunol 168: 4531-4537.

31. Cohen MD, Wei Cl, Tan $\mathrm{H}$, Kao KJ (1986) Effect of ammonium metavanadate on the murine immune response. J Toxicol Environ Health 19: 279-298.

32. Nagase $H$, Okugawa $S$, Ota $Y$, Yamaguchi M, Tomizawa $H$, et a1. (2003) Expression and function of Toll-like receptors in eosinophils: Activation by To1llike receptor-7 ligand. J Immunol 171: 3977-3982.

33. Ikushima H, Nishida T, Takeda K, Toshinori I, Takushi Y, et a1. (2004) Expression of Toll-like receptors 2 and 4 is down-regulated after operation. Surgery 135: 376-385.

34. Conti B, Jahng JW, Tinti C, Son JH, Joh TH (1997) Induction of interferon-Y inducing factor in the adrenal cortex. J Biol Chem 272: 2035-2037.

35. Lammers A, Wieland WH, Kruijt L, Jansma A, Straetemans T, et a1. (2010) Successive immunoglobulin and cytokine expression in the small intestine of juvenile chicken. Dev Comp Immunol 34: 1254-1262.

36. Deng Y, Cui H, Peng X, Fang J, Wang K, et al. (2012) Dietary vanadium induces oxidative stress in the intestine of broilers. Biol Trace Elem Res 145: 52-58.

37. Liu J, Cui H, Liu X, Peng X, Deng J, et al. (2012) Dietary high vanadium cause oxidative damage-induced renal and hepatic toxicity in broilers. Biol Trace Elem Res 145: 189-200.

38. Sarir H, Mortaz E, Karimi K, Kraneveld AD, Rahman I, et al. (2009) Cigarette smoke regulates the expression of TLR4 and IL-8 production by human macrophages. J Inflamm 6:12.

39. Altamirano-Lozano M, Alvarez-Barrera L, Basurto-Alcántara $F$, Valverde $M$ Rojas E (1996) Reprotoxic and genotoxic studies of vanadium pentoxide in male mice. Teratog Carcinog Mutagen 16: 7-17. 